\title{
Amazônia socioambiental. Sustentabilidade ecológica e diversidade social
}

\author{
DEBORAH LIMA e JORGE POZZOBON ${ }^{(+)}$
}

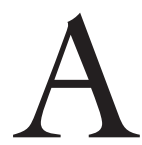

SOCIEDADE OCIDENTAL consolidou, ao longo dos anos de 1990, a adoção de um novo referencial científico para se pensar a relação entre as populações humanas e o meio ambiente. Formado por conceitos provenientes da ecologia e da teoria biológica da evolução, e também influenciado pelas propostas do movimento ambientalista, esse referencial elegeu o conceito de sustentabilidade ecológica como o indicador mais importante de suas análises. Por sustentabilidade ecológica entende-se a capacidade de uma dada população de ocupar uma determinada área e explorar seus recursos naturais sem ameaçar, ao longo do tempo, a integridade ecológica do meio ambiente.

Neste trabalho desenvolvemos a idéia de que o conceito de sustentabilidade ecológica proporciona uma nova base para classificar a diversidade social da Amazônia. Se o critério de racionalidade econômica capitalista ordenava os segmentos sociais segundo seu grau de desenvolvimento e integração ao mercado, o emprego de critérios de sustentabilidade ecológica atribui a segmentos sociais antes inferiorizados uma valoração ecológica positiva. Esses mesmos segmentos sociais, como as populações indígenas, os seringueiros e os ribeirinhos, recentemente denominados "populações tradicionais", incorporaram a marca ecológica às suas identidades políticas como estratégia para legitimar novas e antigas reivindicações sociais. Dito de outra forma, o critério de valoração ecológica confere novas bases para uma valoração política dos segmentos sociais e engendra um novo quadro ordenatório da diversidade social da Amazônia ${ }^{1}$.

\section{Da sujeição à sustentabilidade}

A reformulação de critérios de valoração social, associada à adoção do referencial ambientalista, faz parte de um cenário mundial em que é conferida uma importância tanto científica quanto simbólica à Amazônia. O fato de ser a maior floresta tropical remanescente no planeta preenche o imaginário de toda a comunidade ecologizada do mundo, ao lado de outras questões globais como a perda da diversidade biológica, o efeito estufa e o buraco da camada de ozônio. A construção do paradigma ambientalista é resultado de uma longa reflexão sobre as raízes éticas e ideológicas da crise ambiental que põe em cheque diretamente o modelo de desenvolvimento capitalista, questiona o lugar da espécie humana 
na natureza e sua responsabilidade pelo futuro da biosfera. Esta autocrítica era, até recentemente, impensável.

Em termos de debates acadêmicos, o novo referencial permitiu avanços consideráveis nos estudos sobre a relação entre populações humanas e o meio ambiente na Amazônia. As primeiras tentativas de aplicar conceitos desenvolvidos pela Ecologia ao estudo das sociedades humanas mostraram-se frustrantes. Essas análises limitaram-se a estudar sociedades indígenas, as únicas consideradas adequadas à aplicação dos modelos de ecologia humana inspirados em modelos desenvolvidos para o crescimento de populações animais. Foram produzidas ao longo dos anos de 1960 e 1970, quando a relação entre ecossistemas e populações da Amazônia foi pensada a partir do conceito de adaptação. Rejeitadas por causa de seu caráter reducionista, viam as formações socioculturais dos povos indígenas da Amazônia como adaptações ao ambiente, resultantes da ação da seleção natural - em particular de fatores ambientais limitantes como pobreza dos solos ou carência de proteínas - que teriam impedido o desenvolvimento de formas sociais mais complexas (Meggers, 1977; Gross, 1975; Ross, 1978).

Esse quadro analítico não comportava nossa sociedade "civilizada" porque sua eficiência tecnológica a desvinculava das pressões naturais. Como o desenvolvimento e a história da civilização ocidental teriam se dado independentemente de limitações ambientais, a sociedade ocidental não teria sofrido a mesma pressão dos processos evolutivos que moldaram o desenvolvimento das sociedades indígenas e a ela se reservava o direito a uma "história”. A noção de adaptação era entendida mais como uma forma de sujeição das sociedades indígenas ao domínio da natureza do que como um ajuste que certamente ocorre em sociedades de tecnologia mais simples. O paradigma da sujeição impedia a visualização da relação dialética entre formas sociais e meio ambiente, que implica não uma relação de mão única mas bilateral, pois os povos indígenas também exercem pressões sobre o ambiente e afetam sua evolução (cf. Balée, 1994). Por outro lado, esse mesmo paradigma resultou num relativo atraso da reflexão da antropologia politicamente engajada sobre as relações entre a sociedade humana e o meio ambiente, pois era visto por esta última como produto de uma ideologia que retirava dos índios a condição de sujeitos da história.

$\mathrm{O}$ quadro analítico atual mostra a precariedade epistemológica da dicotomia entre sociedades passíveis de uma análise ecológica e outras isentas. Os povos indígenas aproximaram-se da sociedade nacional seja porque as premissas que o determinismo ecológico adotou perderam seu aval científico, seja porque índios “ingressaram na história” com sua inserção na economia de mercado e no movimento indigenista de luta por direitos de cidadania. Quanto à nossa sociedade, a década de 1990 pode ser considerada o marco de nosso ingresso no time das sociedades com direito a uma análise ecológica: o conceito de desenvolvimento sustentável, embora ambíguo e dotado de polissemia, coloca-nos à frente de um ideal de "adaptação consciente". Aproximamo-nos assim uns aos outros. Envol- 
vimento com o mercado e história ecológica são atributos comuns a sociedades para as quais eram, antes, reservados critérios analíticos distintos.

Uma vez que já não cabem mais as antigas dicotomias, fundadas em conceitos de caráter um tanto apriorístico e que não davam conta da grande diversidade observada em campo, o novo contexto analítico abre espaço para abordagens mais empíricas do que teóricas para estudar a relação entre populações e ecossistemas. Uma análise baseada na verificação empírica da sustentabilidade dos usos que fazem as populações humanas dos ecossistemas, produz, desta forma, uma ordenação da diversidade social segundo critérios ambientais.

O emprego do critério de sustentabilidade - que substitui o de "adaptação" da abordagem teórica evolucionária - permite enumerar as diferentes formas de uso que as populações fazem do meio ambiente, considerando suas diferenças genéricas em termos de inserção na economia de mercado e posse de uma tradição ou história ecológica. Partiremos, inicialmente, de uma explicação a respeito dessas categorias analíticas.

\section{Uma classificação socioambiental da ocupação humana da Amazônia}

Nessa classificação, as categorias socioambientais são distinguidas em termos da pressão de uso e do impacto que exercem sobre o ambiente, relacionados ao modo como ocupam, exploram e concebem sua relação com a natureza. $\mathrm{O}$ comportamento que uma dada categoria socioambiental tem em relação ao ambiente é influenciado por características de sua formação social, tais como a orientação de sua produção econômica, o grau de envolvimento com o mercado e a posse de uma cultura ecológica. No entanto, nenhum atributo social isolado pode ser apontado como responsável pelo diagnóstico de sustentabilidade da ocupação do ambiente, como será discutido a seguir.

Sem pretender cobrir toda a diversidade social da Amazônia, distinguimos nove categorias socioambientais de produtores rurais: povos indígenas de comércio esporádico, povos indígenas de comércio recorrente, povos indígenas dependentes da produção mercantil, pequenos produtores "tradicionais", latifúndios "tradicionais", latifúndios recentes, migrantes/ fronteira, grandes projetos e exploradores itinerantes ${ }^{2}$.

Como em qualquer classificação, as categorias produzidas são ideais e constituem uma simplificação da realidade em um dado momento histórico. Trata-se de um ordenamento da diversidade empírica para permitir uma análise de tendências, e não uma enumeração exaustiva e engessada da variedade socioambiental na Amazônia.

O critério usado para julgar o grau de sustentabilidade ambiental relativo a cada categoria foi baseado em uma avaliação do impacto ambiental de sua ocupação. Uma alta sustentabilidade ambiental significa que a ocupação humana não interfere nos processos ecológicos essenciais para o pleno funcionamento do 
ecossistema. Uma alta sustentabilidade é verificada em uma ocupação que não degrada o ambiente, não provoca alterações microclimáticas, não polui, não destrói hábitats, não explora recursos naturais renováveis acima de sua capacidade de regeneração, nem resulta em extinções de espécies ${ }^{3}$.

Tabela l - Uma classificação socioambiental da Amazônia

\begin{tabular}{|c|c|c|c|}
\hline $\begin{array}{l}\text { Categorias } \\
\text { Socioambientais }\end{array}$ & $\begin{array}{l}\text { Sustentabilidade } \\
\text { Ecológica }\end{array}$ & "Cultura Ecológica" & $\begin{array}{l}\text { Orientação } \\
\text { Econômica }\end{array}$ \\
\hline $\begin{array}{l}\text { Povos indígenas } \\
\text { de comércio esporádico }\end{array}$ & alta & mitógena & autóctone \\
\hline $\begin{array}{l}\text { Povos indígenas } \\
\text { de comércio recorrente }\end{array}$ & média & mitógena & consuntiva \\
\hline $\begin{array}{l}\text { Povos indígenas } \\
\text { dependentes } \\
\text { da produção mercantil }\end{array}$ & baixa & $\begin{array}{c}\text { mitógena/ } \\
\text { "tradicional cabocla" }\end{array}$ & consuntiva \\
\hline $\begin{array}{l}\text { Pequenos produtores } \\
\text { "tradicionais" }\end{array}$ & média & "tradicional cabocla" & consuntiva \\
\hline $\begin{array}{l}\text { Latifúndios } \\
\text { "tradicionais" }\end{array}$ & média & "tradicional cabocla" & rentária \\
\hline $\begin{array}{l}\text { Latifúndios } \\
\text { recentes }\end{array}$ & muito baixa & $\begin{array}{l}\text { não formada/ } \\
\text { depredatória }\end{array}$ & lucrativa \\
\hline $\begin{array}{l}\text { Migrantes/ } \\
\text { fronteira }\end{array}$ & baixa & $\begin{array}{l}\text { não formada/ } \\
\text { emergente }\end{array}$ & consuntiva \\
\hline Grandes projetos & baixa & aplicada & lucrativa \\
\hline $\begin{array}{l}\text { Exploradores } \\
\text { itinerantes }\end{array}$ & muito baixa & depredatória & lucrativa \\
\hline
\end{tabular}

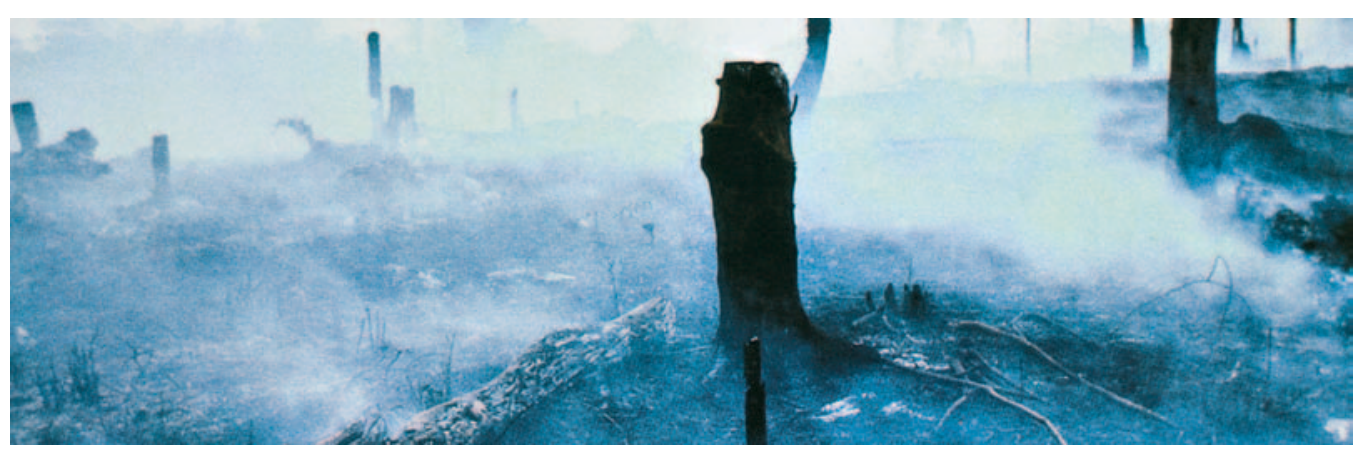

Associado à classificação do grau de sustentabilidade da ocupação, identificamos o tipo de conhecimento que cada categoria socioambiental tem a respeito 
do ambiente que ocupa. Cultura ecológica "mitógena" (advinda do mito) é aquela em que os elementos do ambiente natural são pensados segundo seu papel no mito e seu lugar no cosmo nativo. Esse tipo de cultura ecológica, eminentemente indígena, tem em comum com a cultura ecológica aqui chamada de "tradicional cabocla" a transmissão oral de conhecimentos de uma geração para a outra. Mas à diferença da indígena, a cultura ecológica cabocla compõe-se de fragmentos de diversas tradições (principalmente indígenas e ibéricas), não sendo referida a um cosmo único nem a um ciclo coeso de mitos. No entanto, a cosmologia amazônica não índia tem em comum com as cosmologias indígenas uma perspectiva não dualista - isto é, que concebe uma ordem integrada e comunicante entre a sociedade e a natureza -, como se revela numa série de histórias de transformação de pessoas e espécies animais em seres míticos pelo "encante" (Slater, 1994), além de vastos conhecimentos ecológicos. Como entre as sociedades ameríndias (cf. Descola, 1994; Århem, 1996), a esta cosmo-ecologia não dualista correspondem modelos de interação com o ambiente embasados em uma série de mitos, sanções e tabus que regulam as atividades de exploração de espécies naturais, como o curupira, as mães de "bichos", a panema e outros tantos (Galvão, 1951 e 1955; Da Matta, 1973).

No jargão recente da antropologia ambiental, a sigla "TEK" (Traditional Ecological Knowledge) tem sido usada para denotar tais conhecimentos e práticas tradicionais de baixo impacto ambiental nem sempre racionalizados na forma de um know-how ecológico, mas imersos em campos semânticos que se estendem para além das práticas econômicas propriamente ditas, como a religião e a cosmologia. A denominação aqui adotada - "cultura ecológica" - é mais abrangente do que esta sigla, de modo a permitir uma referência genérica à forma de percepção, aos conhecimentos e às práticas ambientais manifestas por qualquer segmento social - seja uma população tradicional ou outra. O conceito permite chamar atenção para a diversidade dos valores e motivações que informam a prática econômica e o modo como os grupos sociais se relacionam com o meio. Desse modo, a cultura ecológica pode privilegiar valores econômicos do mercado ou valores não materiais; pode levar em conta os processos ecológicos - seja de forma empírica ou metafísica - e guiar suas práticas de acordo com estes, ou desprezar o efeito de suas ações sobre o ecossistema.

Da mesma forma que as implicações da cultura ecológica, e associada a esta, a orientação econômica de uma população também produz efeitos sobre seu grau de sustentabilidade. Por orientação econômica "autóctone" queremos referir não apenas o caráter originário (não colonial) das economias indígenas pouco alteradas, como também o seu caráter de independência com relação ao mercado. A orientação "consuntiva" (de consumo), embora tenha em comum com a "autóctone" o fato de ser voltada para o consumo do grupo doméstico, busca no mercado itens que o grupo considera indispensáveis para sua reprodução. Uma diferença análoga existe entre a orientação "rentária" (de renda) e a orientação "lucrativa". Enquanto a primeira se volta para a reprodução de um certo 
conforto que as oligarquias tradicionais (como os fazendeiros do Marajó, de Roraima, do Baixo Tocantins e do Médio Amazonas) consideram indispensável, a segunda visa à acumulação de capital, o que no meio rural amazônico implica a expansão constante das frentes pioneiras ou a transformação da paisagem florestal para instalar empreendimentos capitalistas a exemplo do projeto Jari, latifúndios do Sul do Pará ou os grandes projetos governamentais, como Carajás.

A pressão de uso que um grupo social impõe ao meio ambiente é determinada por uma combinação de fatores de ordem territorial e geográfica (densidade populacional e condições de transporte e comunicação), econômica (orientação econômica, incluindo as tecnologias de exploração dos recursos naturais, e dependência em relação ao mercado) e cultural (cultura ecológica e demandas sociais). O que se observa no quadro acima é que, sendo um produto multicausal, a sustentabilidade atribuída a uma categoria social corta transversalmente várias dicotomias sociológicas clássicas como índio x branco, camponês x latifundiário, modo de produção doméstico x modo de produção capitalista, orientação econômica voltada para o consumo x orientação para o lucro. Nenhuma dessas dicotomias é capaz de explicar a heterogeneidade na relação com o meio ambiente que as categorias sociais referidas acima apresentam.

Não são os atributos de etnicidade, classe ou orientação econômica de um dado segmento social que definem, por si, seu comportamento em relação ao ambiente, mas a conjugação particular de suas características sociais em um dado momento e lugar. A categoria "índio" não está necessariamente associada à sustentabilidade, nem a de "branco" à insustentabilidade, embora se atribua às sociedades indígenas a herança da sustentabilidade e à população branca o papel oposto. É importante atentar para a cristalização de "estereótipos socioambientais" que atribuem valores ecológicos positivos ou negativos à diversidade social da Amazônia. Uma tal premissa obstrui a construção de uma análise objetiva a respeito da interação complexa entre os processos sociais responsáveis pela degradação ambiental.

Pelo critério de sustentabilidade ecológica apresentado acima, apenas povos indígenas relativamente isolados apresentam, hoje, uma ocupação de baixo impacto ambiental. São sociedades que possuem densidades populacionais baixas, têm alta mobilidade de assentamento, uma demanda sobre recursos naturais limitada e um profundo conhecimento ecológico no qual se baseia não só a sustentabilidade ecológica de sua atividade econômica como a sua cosmologia. O comércio esporádico não chega a modificar este padrão de uso do ambiente. Em geral, o envolvimento com o mercado só implica mudanças socioambientais quando é seguido por alterações significativas no padrão de consumo do grupo, fazendo com que este eleve a pressão que exerce sobre o ambiente para atender à demanda por recursos naturais que o mercado apresenta. No contexto de grupos indígenas, é possível observar uma relação entre grau de envolvimento com o mercado e sustentabilidade ecológica - mas esta não é uma associação válida para toda a diversidade socioambiental. 
Nos grupos indígenas que têm seu território demarcado, apresentam alta densidade populacional e mantêm estreitas relações com o mercado, como os que habitam pequenas áreas indígenas do médio Solimões, esta relação decorre da incompatibilidade entre os sistemas tradicionais de exploração dos recursos naturais e a fixação em um território delimitado. $\mathrm{O}$ aumento da população e o envolvimento crescente na economia de mercado elevam as taxas de exploração dos recursos naturais a níveis acima de sua capacidade natural de reposição. Além do aumento da pressão que estes grupos indígenas exercem sobre os recursos naturais em suas áreas devido ao crescimento das necessidades de consumo, agentes econômicos de fora, que adotam diversas estratégias para usufruir os recursos naturais existentes nas áreas indígenas, contribuem para agravar a pressão de exploração. Como resultado, vários povos enfrentam hoje a escassez de recursos naturais que são essenciais tanto para seu consumo direto como para a venda, e já comprovam a extinção local de várias espécies de plantas e animais.

Em contraste com esta situação, há populações ribeirinhas que apresentam sistemas mais sustentáveis de exploração do ambiente, como as que possuem assentamentos vizinhos a tais terras indígenas no médio rio Solimões. São segmentos camponeses de ocupação histórica e com conhecimentos ecológicos extensos. Embora dependentes do mercado para sua reprodução, a pressão que exercem sobre o ambiente não é da mesma intensidade que alguns povos indígenas porque sua densidade demográfica é regulada por meio de uma alta mobilidade, tanto para outrasáreas rurais quanto para urbanas. Esta mobilidade está associada ao cultivo da mandioca pelo sistema de rodízio e ao sistema de posse da terra por direitos adquiridos pelo usufruto, que não prendem a população a um território fixo. Com efeito, a demarcação de territórios indígenas em áreas reduzidas pode se tornar um fator limitante à auto-sustentação.

No entanto, a densidade demográfica, apontada nesses exemplos como tendo relação direta com o grau de sustentabilidade ecológica, não é um fator suficiente para explicar a pressão de uso de um segmento social. O alto grau de modificação ambiental dos empreendimentos agropecuaristas do sul do Pará é um exemplo contrário. A baixa densidade demográfica nesses latifúndios, principalmente os pecuaristas, não assegurou nem a manutenção da integridade ecológica do ecossistema original, nem a sustentabilidade econômica dos pastos cultivados após o desmatamento (Mattos e Uhl, 1996).

Assim como é falacioso, conforme se viu acima, atribuir valores ecológicos positivos ou negativos a categorias sociais sem levar em conta o caráter múltiplo dos fatores que influenciam a sustentabilidade, assim também seria falacioso supor um comportamento ecológico homogêneo no seio do mesmo "tipo" social ("camponeses", "índios", "latifundiários"). Como acontece com povos indígenas, entre diferentes segmentos camponeses podemos observar quadros socioambientais diversos. Se de fato podemos classificar as populações ribeirinhas da Amazônia e os imigrantes recentes na mesma rubrica de "camponeses", essas populações apresentam graus distintos de sustentabilidade ecológica em 


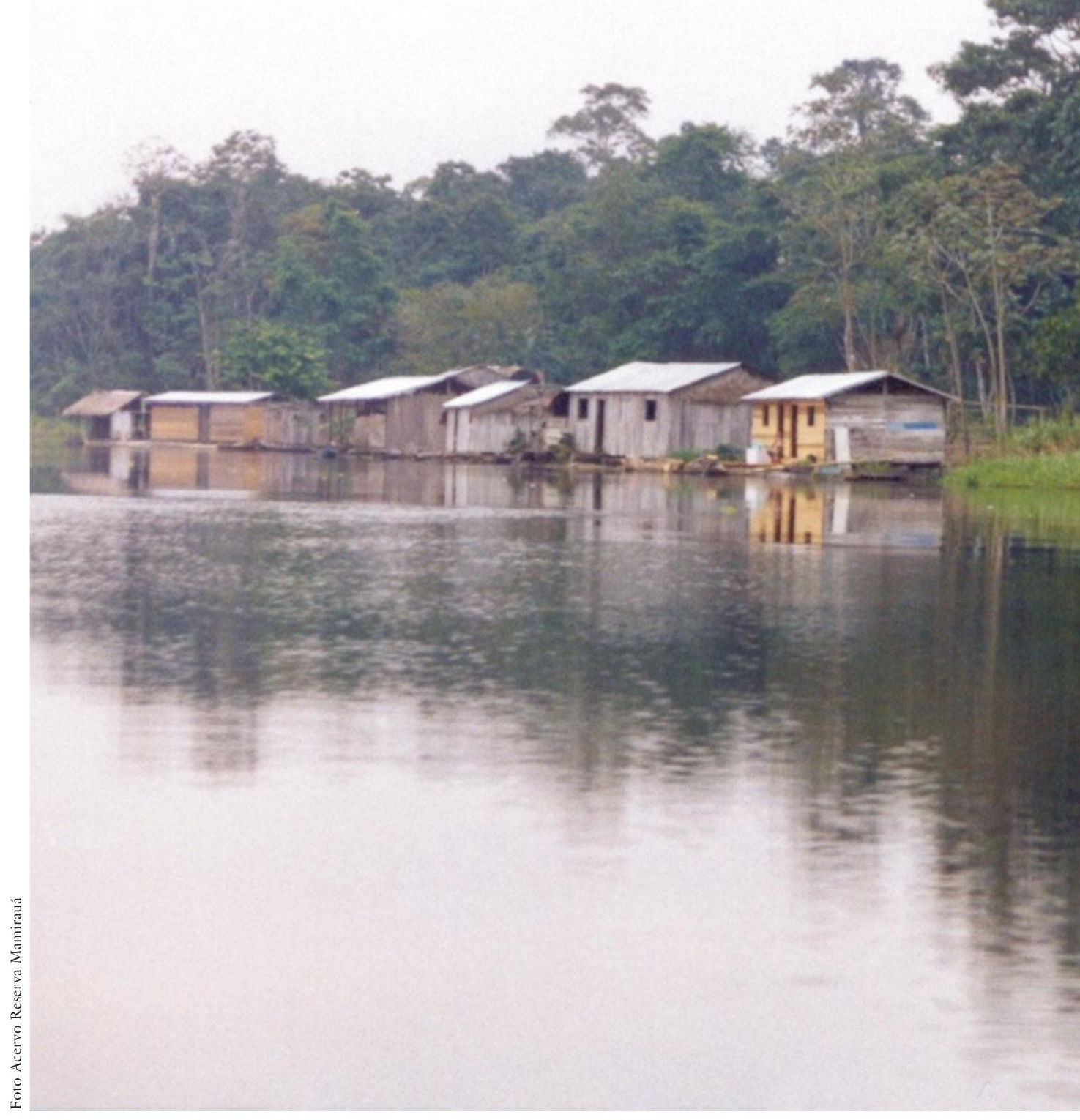

função de suas diferentes culturas ecológicas. As primeiras gerações de migrantes que ocuparam extensas áreas da Transamazônica e de Rondônia muitas vezes tinham seu desempenho econômico prejudicado pelo fato de não saberem utilizar vários recursos da floresta, ao contrário das populações tradicionais (cf. Moran, 1979). Além de estar ligada à falta de conhecimentos sobre formas de uso do ambiente natural, a prática de desmatamento é incentivada pelo fato de legitimar a posse da terra ou, se acompanhada de plantio de pasto, aumentar o valor da terra com vistas à venda para grileiros (Ianni, 1979b; Hall, 1991) .

Da mesma forma, enquanto populações ribeirinhas e migrantes podem ser igualmente qualificadas como populações "pobres", elas apresentam diferentes 


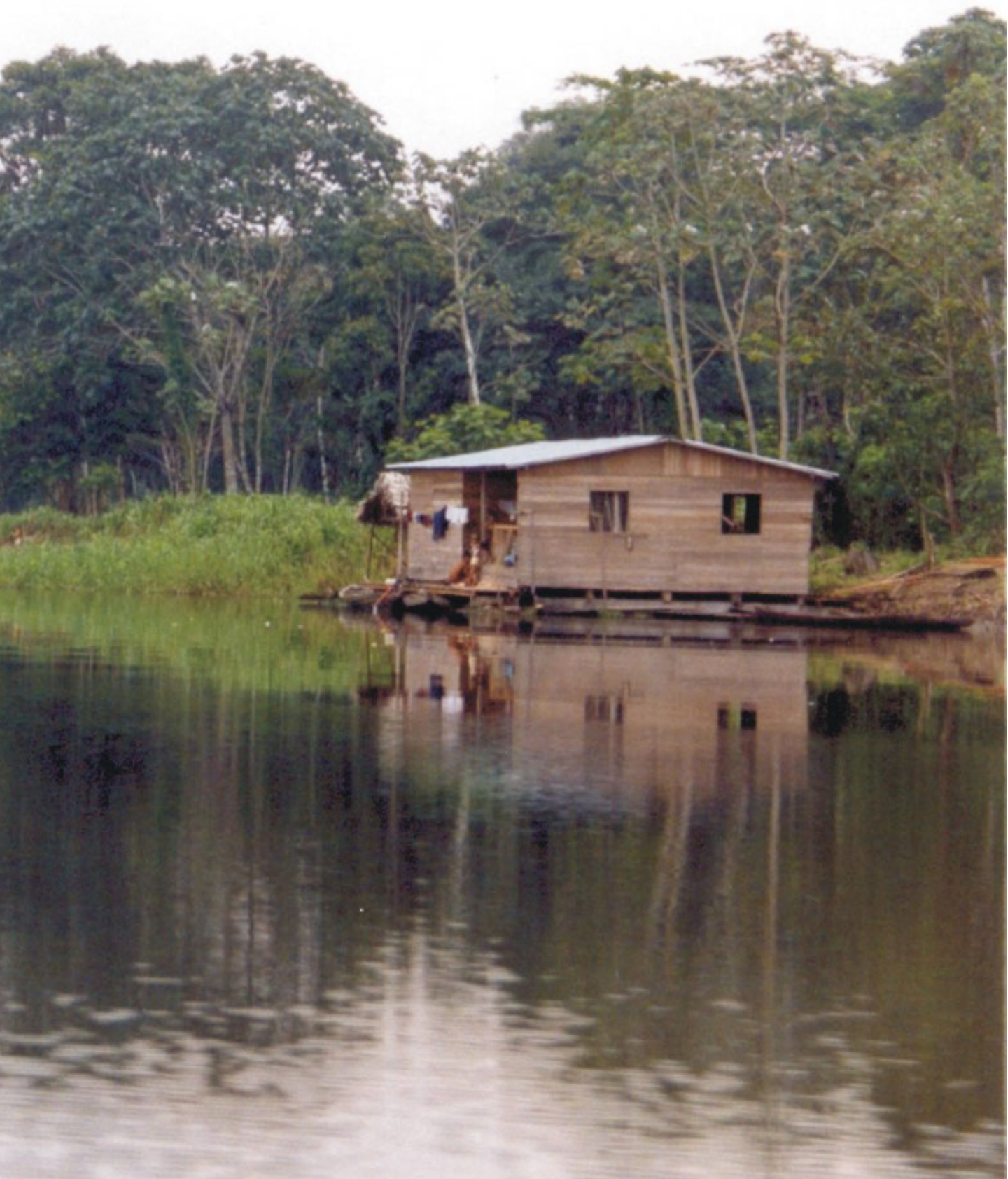

Comunidade ribeirinha da várzea do Paraná do Pananã, região do médio Solimões.

culturas ecológicas e produzem diferentes impactos ambientais, desafiando, deste modo, o consenso expresso no Relatório Brundtland, na Eco 92 e em publicações oficiais, de que pobreza e degradação ambiental estejam necessária e intimamente relacionadas (cf. Cima,1991). Relatórios oficiais mais recentes (como Forsyth, Leach e Scoones, 1998), apresentam novas reflexões sobre a relação entre pobreza e meio ambiente. Como estas não são categorias homogêneas, é preciso identificar, segundo esses relatórios, o contexto que leva segmentos pobres a degradarem o ambiente: geralmente por falta de opções econômicas para sua sobrevivência imediata. Mas nem na Amazônia nem em outras regiões se concede igual atenção à relação entre riqueza e meio ambiente. Dentre as categorias socio- 
ambientais apresentadas acima, os latifundiários recentes, como os proprietários das grandes fazendas do Sul do Pará, são responsáveis por uma das maiores taxas de desmatamento desse estado. Em contrapartida, os latifúndios tradicionais da ilha de Marajó, por exemplo, têm apresentado ao longo do tempo uma relativa capacidade de manter estável a ecologia das áreas que ocupam. Portanto, a sustentabilidade dos assentamentos "ricos", assim como a dos assentamentos "pobres", também depende de fatores como cultura ecológica e orientação econômica.

Feitas essas observações sobre os critérios usados na classificação, passemos agora a um breve exame das especificidades de cada uma das categorias socioambientais apresentadas no quadro acima.

\section{Povos indígenas de comércio esporádico}

Os povos indígenas incluídos nesta categoria são os que ocupam as áreas menos acessíveis e que estão mais distantes das rotas de mercado. São populações que ainda mantêm inalterados seus conhecimentos "mitógenos" sobre o ambiente natural. O território ocupado pelo grupo é objeto de verdadeiros zoneamentos socioambientais nativos: os recursos naturais são localizados e categorizados conforme a pertinência a certos segmentos sociais ligados ao parentesco e à mitologia (aldeias, clãs, linhagens, parentelas, dialetos regionais, áreas sagradas etc.), o que permite o comércio autóctone e uma ampla circulação de recursos geograficamente circunscritos. Em termos de sustentabilidade ambiental, está associada a uma pressão ambiental pouco expressiva, porque a demanda por recursos naturais é baixa e reflete o caráter limitado das necessidades materiais dos grupos.

Os povos nessa situação de contato podem ser distinguidos em duas subcategorias principais: de um lado os povos cujas terras são razoavelmente protegidas de invasões madeireiras, garimpeiras, posseiras ou fazendeiras (como os Enawenê-Nawê no oeste de Mato Grosso); de outro lado, aqueles que, embora sejam de contato recente, têm suas terras periódica ou constantemente invadidas por elementos exógenos (como os Yanomami). A diferença não é circunstancial: o território Enawenê-Nawê é bem menor que o Yanomami; por outro lado, os Enawenê-Nawê são socialmente bem mais coesos e corporativos (Arruda, 1984), ao passo que os Yanomami se subdividem tradicionalmente em dezenas de subgrupos que competem entre si por território (Chagnon, 1974; Lizot, 1977; Albert, 1985), sendo, portanto, muito difícil uni-los em torno do objetivo comum de não fazer alianças com os garimpeiros que invadem anualmente as suas áreas. Tais alianças, além de facilitarem a degradação do meio ambiente, são particularmente desvantajosas para os Yanomami, pois, sendo de contato recente, pouco sabem sobre os valores das mercadorias e aceitam meras bugigangas em troca de quilos de ouro retirados ilegalmente de suas áreas. Entre esses dois extremos, Enawenê-Nawê e Yanomami, há uma grande variedade de casos (como Maku, Waimiri-Atroari, Waiãpi, Wayana).

De acordo com o grau de sustentabilidade ecológica apresentado, diferentes ações podem ser recomendadas, com vistas a promover um incremento ou a 
manutenção de sua sustentabilidade ecológica. Nesse sentido, identificamos o que seriam as demandas ecológicas necessárias para alcançar este fim. Para os índios que se encontram nessa situação de pouco contato, as demandas ecológicas - dificilmente formuladas por eles mesmos, pois lhes falta uma compreensão adequada do funcionamento dos processos político-econômicos da sociedade nacional envolvente - se resumem à prevenção contra certos riscos bastante graves como: desaparecimento devido a doenças para as quais os índios ainda não desenvolveram defesas naturais; desaparecimento devido a massacres praticados por invasores ilegais, como garimpeiros, madeireiros, posseiros, grileiros e narcotraficantes (estes últimos, sobretudo nas áreas de fronteira com a Colômbia); poluição dos rios por mercúrio e outros produtos usados pelos garimpeiros; desmatamento seletivo e predatório praticado pelos madeireiros, provocando alterações na morfologia do solo, assoreamento dos mananciais e baixa na piscosidade dos cursos de água (cf. Capobianco e Giannini, 1995; Macedo, Giannini e Tatto, 1997; Macedo, Giannini, Andreas e Ladeira, 1997); e alterações nos padrões de tradicionais de assentamento.

No caso dos índios de contato recente, as demandas ecológicas de prevenção contra alterações nos padrões tradicionais de assentamento se ligam indissociavelmente a certas demandas sociais:

- demarcação criteriosa do território como garantia da manutenção da orientação econômica "autóctone";

- estratégias sanitárias capazes de atender os índios sem alterar os padrões tradicionais de assentamento (equipes volantes de saúde, formação de agentes indígenas de saúde, programas itinerantes de educação sanitária etc.);

- estratégias de vigilância do território que não alterem os padrões tradicionais de assentamento (criação de postos nos pontos-chave do território indígena; habilitação de índios para operar radiofonia, motores de popa ou viaturas; definição de rotinas em caso de invasão, tais como a comunicação imediata do fato aos interlocutores na sociedade civil, o acionamento do Ministério Público, da Funai e da Polícia Federal para a expulsão dos intrusos).

Em geral, os povos indígenas de comércio esporádico demonstram pouca compreensão sobre o mundo das mercadorias, podendo, como vimos, ser facilmente enganados pelos garimpeiros e outros intrusos em troca de "bugigangas" de valor bem inferior à quantidade de trabalho ou produtos que os índios doam em troca. Isto se deve, obviamente, ao fato de que esses índios não conseguem conceber o valor relativo das mercadorias em termos de seu padrão universal de medida - o dinheiro.

\section{Povos indígenas de comércio recorrente}

Já os grupos indígenas que mantêm relações comerciais recorrentes com a sociedade local e regional demonstram compreender bem melhor as operações monetárias e o valor relativo das mercadorias. Essa mudança de perspectiva devese a uma transformação profunda na relação dos nativos com a mercadoria: se na 
primeira fase de contato com o comércio, as mercadorias são artigos de luxo, a cuja utilidade os índios costumam agregar um valor estatutário (possuí-los torna um indivíduo mais importante aos olhos de seus pares), ou enquadrá-las a um referencial simbólico que lhes confere valor segundo significados particulares ao grupo, na segunda fase certas mercadorias deixam de ser apenas a marca de um status diferenciado e passam a ser consideradas indispensáveis (cf. Hugh-Jones, 1992). Incluem-se nessa rubrica certas ferramentas (como machados, terçados, facas, anzóis, espingardas), roupas e medicamentos de uso simples (analgésicos, anti-sépticos, vermífugos etc.). Na eventualidade de um corte súbito no suprimento de mercadorias, os povos indígenas nessa situação ainda dispõem de mulheres e homens mais velhos capazes de substituir os itens em falta por suas contrapartidas nativas. Nesse sentido, ainda não se observa uma perda significativa dos conhecimentos ecológicos do grupo como um todo. Porém, a presença cada vez mais significativa da escola, a decadência paulatina da transmissão tradicional de conhecimentos e o uso cada vez mais intenso de produtos industrializados tornam a cultura ecológica "mitógena" progressivamente restrita aos velhos, pondo em risco sua continuidade.

A categoria "povos indígenas de comércio recorrente" abrange uma grande diversidade de situações sociais - incluindo, na verdade, a maioria dos povos indígenas da Amazônia -, cujo traço comum é o fato de que a produção para a venda já é incorporada nas práticas culturais. Em geral, trata-se de povos localizados ao longo das principais vias de comunicação.

Do ponto de vista da estrutura de mercado, podemos distinguir três situações típicas: ou os índios se integram ao sistema tradicional de "aviamento", ou participam de um tipo de extrativismo mais recente e bem mais depredatório, que envolve basicamente o garimpo e a comercialização de madeiras nobres, ou ainda participam do que podemos chamar de sistema mediado de comercialização.

1. Sistema tradicional de aviamento. É originário do antigo regime do "barracão", consolidado no final do século XIX durante o ciclo da borracha. Naquela época, os patrões seringalistas controlavam certas bocas de rio, onde estabeleciam seus "barracões", entrepostos comerciais que "aviavam" (adiantavam) mercadorias aos seringueiros, que tinham de pagá-las com borracha. Por meio desse escambo monetizado, era possível imobilizar a força de trabalho através de uma escravidão pela dívida, pois eram os patrões quem manipulavam as contas de seus fregueses. $\mathrm{O}$ sistema que sobreviveu à queda da borracha e se transformou em prática corrente em todo o oeste da Amazônia, até nossos dias, é usado para explorar não apenas a borracha natural, mas também outros produtos florestais como cipó, piaçaba, copaíba, peixes ornamentais, frescos, secos e salgados, madeiras, peles, farinha de mandioca e artesanato indígena tradicional. No lugar dos barracões, há os "regatões", comerciantes embarcados que possuem uma rede arborescente de fregueses cujas embarcações cada vez menores penetram os altos rios em busca de clientes ainda mais humildes, que, por seu turno, exploram o índio - o freguês sem freguês. Como no ciclo da borracha, o índio jamais 
consegue saldar suas dívidas e só não reage por temor a um corte drástico no suprimento de mercadorias e medicamentos, de que se tornou dependente ao longo dos anos. Exemplos típicos de integração com o comércio local no estilo "regatão" se encontram no alto rio Solimões, envolvendo índios Ticuna, e em todo o vale do rio Negro, envolvendo grupos Tukano e Arawak (cf. Ribeiro, 1970; Oliveira Filho, 1988; Meira, 1993).

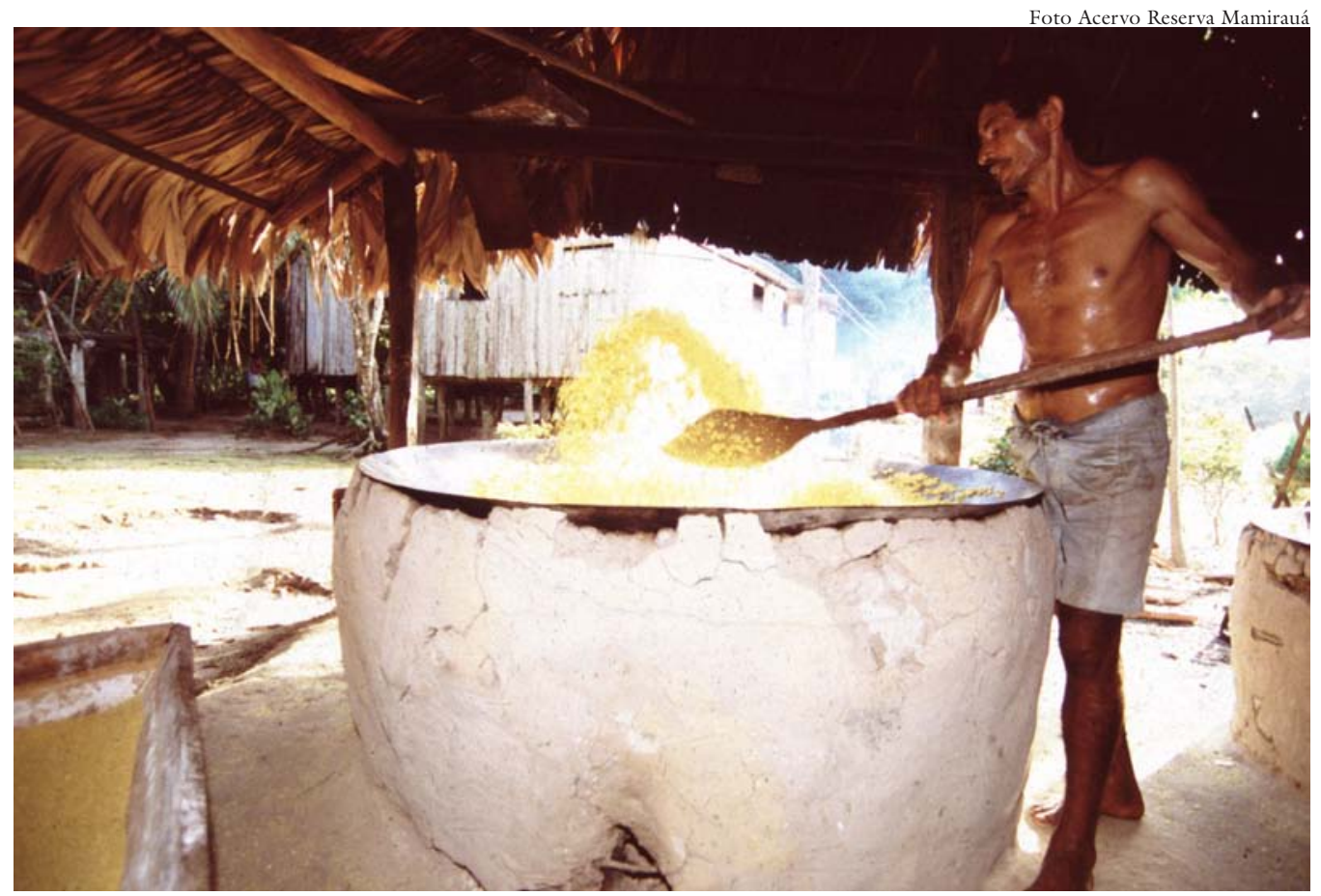

Ribeirinho fazendo farinha: sistema de pequenos produtores tradicionais.

\section{Extrativismo recente.}

2.1. Garimpo. Na Amazônia, as frentes garimpeiras datam, em sua maioria, da segunda metade do século XX. Sua presença nas áreas indígenas é ilegal e sempre resulta de invasões mais ou menos espontâneas. Afora casos de brutalidades como a que se praticou em 1993 contra os Yanomami de Haximu, pode-se dizer que o garimpeiro busca muito mais seduzir o índio para agir em seu favor, quanto mais não seja para não atrair ações legais de desintrusão, com presença da Polícia Federal, do Ibama e das Forças Armadas, a exemplo do que tem ocorrido entre os Kayapó, no sul do Pará. Em contextos politicamente articulados e organizados, como é o caso dos índios do vale do rio Negro, a presença dos garimpeiros é rapidamente percebida como indesejável. Porém, entre os Kayapó, de contato mais recente e tradicionalmente muito faccionalistas, os efeitos do garimpo são bastante nefastos: além da depopulação devido às doenças, há o aliciamento de lideranças, com surgimento de privilégios econômicos em detrimento da maioria. Em termos estritamente ambientais, há o mercúrio jogado nas águas posteriormente ingeridas, cujo efeito mais deletério são as anomalias de formação nos fetos humanos, e, finalmente, o desmatamento das barrancas 
dos cursos d'água, com o assoreamento dos rios, o descontrole das cheias e a escassez de caça e pesca (Oliveira, Meira e Pozzobon, 1994).

2.2 Exploração de madeira. O que foi dito acima sobre a ação dos garimpeiros pode-se afirmar também da ação dos madeireiros: presença ilegal nas áreas indígenas garantida por meio de alguma violência física contra os índios, sempre abrandada pelo aliciamento de lideranças através de presentes às vezes bem caros, como viaturas utilitárias e aviões. Aí está a diferença em relação ao garimpo: os madeireiros mobilizam muito mais verbas. Por isso também podem pagar capangas e matadores, que, se não chegam a praticar o genocídio, encarregam-se de eliminar indivíduos - índios ou não - que eventualmente resistam ao roubo de madeira nas áreas indígenas. Porém, o efeito social é semelhante ao do garimpo: cria-se um grupo privilegiado de lideranças cooptadas, enfraquecendo com isso o tecido social nativo e as instituições em que se funda a autonomia econômica e cultural do grupo. Os exemplos mais característicos de envolvimento de índios com a exploração ilegal de madeiras na Amazônia são os Kayapó, no sul do Pará, e os Guajajara, no oeste do Maranhão (Macedo, Giannini e Tatto, 1997; Macedo, Giannini, Andreas e Ladeira, 1997; Pozzobon, 1999).

3. Comércio mediado. Sob esta rubrica, podemos incluir uma série de iniciativas por parte de agências "indigenistas", visando a direcionar a produção indígena para o mercado, ou facilitar-lhe o acesso ao mercado, ou ambas as coisas. De acordo com o modo da mediação feita, podemos dividi-la em mediação tutelar e mediação com parceria.

3.1. Mediação tutelar. No mais das vezes praticada pela Funai e pelas missões religiosas. Inspirados na vaga idéia de que os índios precisam produzir algo para adquirir as mercadorias que desejam e animados pelos capitais recentemente colocados à disposição através de financiamentos internacionais de caráter ecológico (Prodeagro, Planafloro, PPG7), missionários e funcionários da Funai dão-se à elaboração dos chamados "projetos produtivos sustentávais". Em geral, trata-se de iniciativas pouco sustentáveis e muito frustrantes para os índios: primeiro, devido à solução de continuidade, decorrente de más avaliações da capacidade de absorção dos mercados locais e regionais; segundo, porque não treinam índios para administrar a produção e a comercialização de produtos nativos (daí o caráter tutelar).

3.2. Mediação com parceria. Incluem-se aqui as parcerias entre organizações indígenas e ONGs ou institutos de pesquisa. Ao contrário da mediação tutelar, o que se visa neste caso é à transferência de novas tecnologias ou adaptação de tecnologias nativas à exploração ecologicamente sustentável de produtos que realmente possam igualar os índios aos demais produtores e demovê-los das alianças com a exploração ilegal e depredatória de suas áreas. Mencionamos como exemplo o caso dos índios Xikrim, em cujas terras está-se implementado a produção de madeiras nobres com plano de manejo ambiental, envolvendo gestões junto aos compradores internacionais para colocar no mercado a produção com a marca publicitária "indígena” e, portanto, “ecologicamente correta” (cf. Capobianco e Giannini, 1995). 
As experiências com parcerias entre índios, de um lado, e institutos de pesquisa ou ONGs, de outro, mostram as vantagens de se integrar os conhecimentos ecológicos nativos ainda existentes na produção competitiva para o mercado. Assim, pode-se dizer que as demandas ecológicas dos índios de comércio recorrente, além das medidas preventivas referidas na seção anterior ("Povos indígenas de comércio esporádico"), envolvem basicamente a gestão ambiental e as alternativas econômicas que, sendo ecologicamente sustentáveis, sejam ao mesmo tempo capazes de conferir competitividade à produção indígena. Quanto às demandas sociais destes grupos, trata-se de garantir o apoio por parte do poder público e de agências não governamentais para melhorar as condições de acesso à saúde, à educação e à fiscalização das terras.

\section{Povos indígenas dependentes da produção mercantil}

Nesta categoria estão representados os grupos que, ao perderem sua capacidade de produzir diretamente os principais recursos para sua sobrevivência, passaram a depender do mercado para obter o consumo básico. Entre os grupos que compõem esta categoria, a pior situação é a das terras indígenas pequenas e localizadas nas proximidades de centros urbanos. Porque apresentam altas densidades demográficas e elevadas demandas sociais de consumo, os recursos naturais que constituem a base da subsistência de outros grupos, como a caça e outros produtos da extração florestal, foram esgotados. Em alguns casos, mesmo a área de cultivo é limitada e não permite o rodízio ideal de capoeiras. O escasseamento dos principais recursos naturais e o crescimento da população indígena são responsáveis por uma alta pressão de uso sobre o ambiente. Sem a necessária sustentabilidade ecológica, essas áreas não se mantêm economicamente. A sobrevivência depende quase inteiramente da produção mercantil, sendo muitas vezes complementada por trabalhos assalariados nas cidades. Em comparação com produtores não índios, descritos abaixo, têm a desvantagem de estarem ligados a um território que, se lhes garante o reconhecimento da singularidade étnica e lhes oferece os supostos benefícios da tutela governamental, não thes permite sobreviver de acordo com seu modelo econômico tradicional, colocando-os frente ao dilema de viver num ambiente economicamente desfavorável ou de migrar para as cidades ou áreas rurais mais distantes e perder os benefícios ligados à territorialidade.

Estão nessa situação terras indígenas localizadas no médio e alto Solimões, próximas às cidades de Tabatinga, Benjamin Constant e Tefé: T. I. Sto. Antônio, Bom Intento e Umariaçu; T. I. Barreira da Missão, e T. I. Marajaí (Atlas Ticuna 1998; Lima 1998). A densidade demográfica encontrada na T. I. Santo Antônio, por exemplo, é de 112 habitantes por $\mathrm{km}^{2}$. Em situações tão extremas, as terras indígenas são praticamente bairros das cidades adjacentes e servem apenas como local de residência.

Também se encontram em situação de baixa sustentabilidade ecológica os moradores de aldeias com populações excepcionalmente grandes - acima de mil 
habitantes - que chegam a constituir verdadeiros assentamentos urbanos. No alto Solimões, são exemplos dessas aldeias os assentamentos Ticuna Belém do Solimões, com 2.508 habitantes, Campo Alegre, 2.882 habitantes, Betânia, com 2.056 habitantes, Vendaval, 1.162 habitantes, e a aldeia Feijoal, 1.155 habitantes (Oliveira Filho, 1998). Somadas, as populações destas cinco aldeias representam $5,4 \%$ de toda a população indígena da Amazônia Legal, estimada em 180 mil índios (Fany Ricardo, 1999). Mesmo localizadas em terras indígenas relativamente extensas, seus moradores não têm, em seu entorno, recursos naturais com densidades suficientes para prover a subsistência pelos padrões tradicionais.

Essas populações são conscientes da sua problemática particular. Em recente trabalho de consulta, lideranças indígenas do médio e alto Solimões apresentaram como demandas socioambientais o desenvolvimento em alternativas econômicas de produção (piscicultura, avicultura, reflorestamento e plantio de ervas medicinais), saneamento básico, abastecimento de água e tratamento do lixo. Preconizam o desenvolvimento de sistemas de manejo ambiental para garantir sua sobrevivência, apontam a necessidade de apoio à fiscalização das terras, requerem cursos para formação de agentes ambientais indígenas e reclamam o fortalecimento das instituições governamentais ligadas à questão indígena (Lima, 1998).

\section{Pequenos produtores "tradicionais"}

Por pequenos produtores tradicionais queremos nos referir à população originária do processo de colonização ibérica da Amazônia. As características de sua formação histórica, a posição que ocupam na estrutura social e os trezentos anos de existência, permitem caracterizá-los como o "campesinato histórico" da Amazônia (cf. Lima, 1992; Nugent, 1993; Harris, 1996). Apesar de essa terminologia fazer referência a uma população extensa e heterogênea, os critérios de classificação aqui adotados permitem agrupá-la em uma única rubrica. Se abstra-irmos a especificidade territorial dos índios, a etnicidade e a condição tutelar de sua relação com o Estado, as características da economia doméstica dos produtores tradicionais e dos grupos indígenas dependentes da produção mercantil é a mesma.

Desde o início, este camponês moderno (produto do projeto colonial mercantil), recebeu de forma impositiva um padrão cultural de consumo de artigos manufaturados que, por ser um dos requisitos para se aproximar da condição de civilizado, foi a razão por que se tornou produtor voluntário de mercadorias. Coletor de drogas do sertão, de borracha, de castanha, de juta e malva, agricultor de pequena escala, caçador, pescador etc., foram vários os trabalhos que the couberam ao longo dos diversos ciclos que caracterizaram a história econômica da Amazônia (cf. Veríssimo, 1970 [1878]; Galvão, 1955; Wagley, 1976; Benchimol, 1999). Nessa trajetória, o sistema de aviamento e a patronagem consistiram na principal relação de produção da Amazônia, regulando o acesso aos produtos naturais com valor comercial e às mercadorias básicas para a sobrevivência "civilizada".

Após a queda do aviamento e, em seguida, a migração dos antigos patrões para as cidades, os domínios da exploração extrativista passaram a ser ocupados 
por pequenos assentamentos habitados pelos antigos fregueses, libertos da sujeição comercial. Em tais áreas, como no Acre, ao longo do Amazonas-Solimões e na região das ilhas do Estuário, a posse passou do domínio mercantil dos patrões à ocupação simples, baseada na permanência histórica, mas sem base legal. Tanto os seringueiros do Acre, quanto os pescadores-agricultores do Solimões, Amazonas e Estuário sentiram a pressão da competição por recursos naturais que pecuaristas, pescadores equipados com geleiras e redes, e madeireiros utilizando tratores e motosserras impuseram em suas áreas de exploração tradicional. A reação política culminou na organização de movimentos sociais importantes, que encontraram no discurso ambientalista o suporte necessário para suas reivindicações sociais. Das parcerias que formaram com ambientalistas, receberam a denominação "populações tradicionais," como uma maneira de diferenciá-los e reconhecer neles um papel potencial para o desenvolvimento de um novo modelo de uso do ambiente (Carneiro da Cunha e Almeida, 1999). A nova legislação sobre unidades de conservação (SNUC), por exemplo, concede apenas às sociedades tradicionais o direito ao usufruto e à ocupação nesses territórios reservados à conservação e ao manejo sustentável do ambiente.

A base da escolha do campesinato histórico como integrantes das populações a serem ecologicamente valorizadas precisa ser analisada para não se cair em suposições românticas nem imputar-lhes, ou esperar dessas populações, uma condição social estática (Lima, 1997). A pressão de uso que exercem sobre o ambiente não afeta negativamente a sustentabilidade ecológica devido a uma combinação de fatores intencionais e limitantes. A produção doméstica tem por objetivo garantir o consumo dos membros da família e dessa orientação consuntiva decorre a lógica da aplicação dos rendimentos do trabalho. É a satisfação das necessidades de consumo que orienta a produção e, portanto, influencia a pressão de uso sobre o ambiente. Esta orientação é subjetiva no que se refere à definição de limites à produção e apresenta-se como fator limitante da produção. De acordo com as análises da microeconomia camponesa desenvolvidas por Chayanov (1966; cf. Abramovay, 1998), explorar a própria força de trabalho leva a considerar o custo da penúria do esforço em relação ao benefício do consumo extra. Há também limitações tecnológicas que reduzem a capacidade de explorar o ambiente a taxas mais altas, bem como restrições para o acesso ao mercado que surtem efeitos negativos sobre o volume de produção.

Por outro lado, sendo a economia doméstica voltada ao sustento do grupo familiar, a visão dos produtores sobre a conservação tem o sentido de garantia de manutenção do seu modo de vida. A competição desigual dos exploradores “de fora" ameaça a sobrevivência dos produtores, pois são eles quem sofrem diretamente as conseqüências da redução dos estoques de recursos naturais. Por esse motivo, os movimentos “socioambientais” que deflagram, seja para a constituição de reservas extrativistas, reservas de lago ou por sua inclusão em outras categorias de unidades de conservação, têm para eles o significado de apropriação territorial e segurança contra a entrada de exploradores comerciais. 
Como tendência geral, caso não sejam atendidas suas demandas ecológicas por defesa do território, apoio ao desenvolvimento e aplicação de sistemas de manejo sustentáveis, sua contribuição à sustentabilidade ecológica poderá decrescer em função do incremento populacional e do aumento do consumo de mercadorias compradas.

\section{Latifúndios "tradicionais"}

Até a década de 1960, a pecuária na Amazônia era praticada apenas em campos naturais de seis regiões: os "lavrados" de Roraima, Rondônia e Amapá, os campos aluviais do médio e baixo Amazonas e os do Marajó, bem como nos campos seminaturais às margens do rio Acre (Villela, 1966). Os latifúndios surgidos nessas zonas são antigos, datando grande parte do século XVIII. O caráter histórico desses latifúndios aparece também nas relações de trabalho. Os atuais vaqueiros e capatazes descendem a maioria de antigos escravos que passaram tecnicamente à condição de agregados e dependentes após 1888 (Ximenes, 1997). O pagamento de seus serviços se dá parcialmente em espécie, parcialmente em autorizações para pesca, caça e extrativismo, bem como a agricultura de subsistência e a pecuária em pequena escala nos domínios do patrão. Ademais, não é rara a prática do aviamento, isto é, do endividamento do "vaqueiro" no armazém da fazenda. Em consonância com isto, desenvolveram-se entre este e o patrão relações bastante estáveis de trabalho, no mais das vezes baseadas num sistema clientelista, em que a contradição entre capital e trabalho se amortece na linguagem aparentemente igualitária do compadrio, da confiança mútua, da lealdade, da amizade e da parceria (Lobo, 1998). A despeito do baixo padrão zootécnico do gado, da baixa taxa de lotação das pastagens naturais utilizadas e do caráter tradicional, pouco flexível, das relações de trabalho, até os anos de 1970 o latifúndio tradicional amazônico garantia ao fazendeiro uma renda estável (Ximenes, 1997). Portanto, a orientação econômica destes latifúndios tradicionais não é a da acumulação de capital e expansão territorial, como os latifúndios recentes, mas a da manutenção de um conforto e um domínio senhoreais. Isto produz, sem dúvida, algumas conseqüências importantes em termos de sustentabilidade. Os dados mostram que o latifúndio tradicional é bem menos impactante e bem mais sustentável que o latifúndio recente: enquanto as pastagens cultivadas em áreas de desmatamento chegam à degradação entre sete e dez anos, nas áreas de pastagens nativas a natureza original permanece pouco modificada, apesar da antigüidade da exploração pecuária (Ximenes, 1997). O caráter sustentável dos latifúndios tradicionais associa-se igualmente a uma cultura ecológica de tipo tradicional "cabocla", fruto de uma histórica familiaridade com o ambiente natural e de técnicas exploratórias de baixo impacto.

A partir da década de 1970, um outro sistema pecuário é implantado na Amazônia, também com base no latifúndio mas com pastagem cultivada em áreas desmatadas. Este processo de substituição ecológica implicou uma queda substantiva da participação do latifúndio tradicional no rebanho total da Amazô- 
nia. No Pará, por exemplo, de 1974 a 1994, o rebanho bovino cresceu em 547\%, sendo que no mesmo período a participação dos latifúndios tradicionais marajoaras caiu de $38,13 \%$ para $6,86 \%$ (Ximenes, 1997). A produtividade comparativamente baixa dos latifúndios tradicionais e os baixos lucros que proporcionam têm colocado o latifúndio tradicional em desvantagem com relação ao latifúndio recente.

Para enfrentar essas dificuldades, alguns fazendeiros tradicionais começam a instalar pastagens cultivadas nas áreas de floresta de terra firme, dando curso ao processo de substituição ecológica iniciado pelos latifúndios recentes. Essa mudança introduz a necessidade de novos insumos (fertilizantes, defensivos químicos, combustíveis fósseis, eletrificação) e novas técnicas (melhoramento genético das pastagens e do rebanho). Com isso, entram em decadência as relações tradicionais de trabalho, baseadas no antigo sistema clientlista. Como alternativa a este cenário cada vez mais presente, alguns fazendeiros do Marajó têm explorado o turismo ecológico, estimulados pelo atual governo do Pará (Ximenes, 1997), na esteira da recente busca generalizada de sustentabilidade ecológica para a Amazônia.

\section{Latifúndios recentes}

A formação de latifúndios em áreas do interior da Amazônia começou apenas no final da década de 1950, a partir da expansão territorial de fazendeiros do sul do país. Estes se interessavam em obter lucros futuros com a revenda das terras, na época muito baratas, ou com a exploração do potencial econômico quando se abrissem vias de comunicação, tornando-as mais acessíveis. Só depois, na década de 1960, é que este movimento de ocupação do interior amazônico pelos grandes proprietários de terras foi impulsionado por meio de políticas governamentais específicas, notadamente os incentivos fiscais concedidos a projetos agropecuários pela Superintendência do Desenvolvimento da Amazônia, a Sudam, criada em 1966. Por trás da política militar de integração nacional, havia de fato a grande expansão territorial do capital rumo à Amazônia. Em duas décadas, o capital privado foi atraído com programas de crédito e incentivos fiscais para estabelecer extensas propriedades no sul do Pará principalmente, mas também em Rondônia, no norte do Mato Grosso e no Acre (Branford e Glock, 1985). Os projetos agropecuários financiados pelo governo militar representaram o primeiro movimento de um processo contínuo de formação de extensos domínios privados no interior da Amazônia, trazendo graves consequiências sociais e ambientais para a região. A expansão da fronteira capitalista tinha como base a destruição da cobertura vegetal. A floresta representava "desocupação", "vazio demográfico" e subdesenvolvimento. A expressão legal desta concepção durante os anos de 1970 era a concessão de títulos sobre seis hectares para cada hectare de floresta desmatada (Uhl e Almeida, 1996). Com isso, instalou-se um amplo processo de substituição ecológica, baseado no desmatamento e na formação de pastagens cultivadas.

O alto custo social da implantação desse processo é concretizado na expulsão, no massacre ou no deslocamento de grupos indígenas inteiros para reservas 
distantes do território de origem, no trabalho escravo, na expulsão de posseiros, na violência e nos conflitos pela posse da terra, resultantes da extrema concentração fundiária que se instalou na região (cf. Hall, 1991).

Hoje é consenso atribuir à pecuária a responsabilidade pelas maiores taxas de desmatamento da Amazônia. A conversão de um hectare de floresta tropical em pasto resulta num ecossistema bastante empobrecido: um espaço vertical de $40 \mathrm{~m}$ contendo aproximadamente 350 toneladas de biomassa e milhares de espécies animais e vegetais se transforma num campo com apenas dez toneladas de biomassa, compactada num espaço vertical de um ou dois metros dominado por uma ou duas espécies exóticas de capim (cf. Mattos e Uhl, 1996, p. 60; Almeida e Uhl, 1996, p. 119).

A insustentabilidade ecológica desta forma de ocupação é sintomaticamente acompanhada de seu fracasso como empreendimento econômico: devido à vida curta das pastagens plantadas em solos pobres (de sete a dez anos, como se viu acima) e a sua fragilidade ao ataque de pragas animais e ervas daninhas, os empreendimentos se vêem atualmente obrigados a buscar alternativas de sustentabilidade econômica.

\section{Migrantes/ fronteira}

À semelhança do latifundiário recente, o trabalhador rural que se estabelece como posseiro nas frentes amazônicas de expansão agrícola utiliza-se do desmatamento como forma de legitimar sua ocupação. No entanto, as semelhanças terminam aí, pois no primeiro caso, o desmatamento é originário de uma política de ocupação de "vazios demográficos" e "vazios econômicos" através da concessão de títulos fundiários e incentivos fiscais por parte do poder público, ao passo que no caso dos migrantes trata-se principalmente de uma tomada espontânea de posse, cuja expressão é a área desmatada, que passa então a ser vista como benfeitoria na tentativa de garantir o direito de ocupação. Ademais, dado o caráter doméstico de sua produção, o posseiro não desloca os resultados de sua atividade para a região de origem, como faz o latifundiário. Pelo contrário, a região de origem é fonte de "parceiros" na formação dos novos núcleos que se vão estabelecendo nas frentes de expansão agrícola a partir dos anos de 1960 e 1970.

Oriundos a maioria do nordeste e do sul do país (Ianni, 1979a; Hébette, 1991), esses migrantes chegam à Amazônia premidos pela escassez de terras em suas regiões de origem. O caráter recente do estabelecimento das posses tem implicações ambientais importantes. Além de portadores de um conhecimento ecológico limitado da floresta, concentram seus esforços em cultivos exóticos e impactantes para o ambiente tropical, principalmente as culturas intensivas e perenes que implicam a remoção da cobertura florestal.

Acrescente-se que, na ausência de uma cultura ecológica específica da região, a população de migrantes deixa de se beneficiar de uma série de recursos naturais de que o "caboclo" faz amplo uso, tais como ervas medicinais, frutas e tubérculos selvagens, cipós e outros materiais de construção. Não compartilhan- 
do um conhecimento da floresta que se traduza não apenas em técnicas de manejo, mas também em uso do ambiente mais amplo e socializado, pratica a caça, a pesca e o abate de madeiras nobres sem a preocupação de preservar para seus descendentes. Não há, enfim, um passado econômico no local - daí a busca de investimentos a curto prazo e de caráter depredatório, como a exploração de madeiras nobres e a criação de gado em áreas de desmatamento.

A ausência de uma tradição ecológica e de um passado econômico ligados à Amazônia permitem incluir nesta mesma categoria, ao lado dos posseiros, os trabalhadores rurais que têm pouca ou nenhuma garantia de posse da terra, tais como os trabalhadores sem terra e os sazonais ligados às grandes fazendas. $\mathrm{O}$ aspecto político da presença desses três segmentos sociais na Amazônia reforça a inclusão de todos eles na mesma categoria socioambiental: são marcados por uma trajetória de grandes sofrimentos, advindos não apenas da incerteza decorrente de qualquer transumância e colonização de territórios inexplorados, mas principalmente da violência que têm caracterizado as áreas de ocupação recente na Amazônia.

\section{Grandes projetos}

O que se convencionou chamar de "grandes projetos" são empreendimentos desenhados pelo Estado a fim de implantar autoritariamente enclaves capitalistas para o desenvolvimento da Amazônia. Envolvem pesados investimentos federais em infra-estrutura viária, geração de energia através de grandes hidrelétricas e megaprogramas de exploração industrial de minérios, além de políticas de incentivos fiscais para o investimento de capital privado na agropecuária baseada em latifúndio ou na exploração mineral em escala de indústria. Justificados pela política de integração nacional - face ideológica da implantação autoritária do capitalismo no interior do país durante a ditadura militar nos anos de 1960 e 1970 - tais projetos não demonstravam inicialmente qualquer preocupação com o ambiente natural.

A partir de meados dos anos de 1980, esse modelo de ocupação capitalista forçada começa a ser questionado. Pressões internacionais, por meio das agências financiadoras de projetos de desenvolvimento, tais como o Banco Mundial, introduzem o conceito de desenvolvimento sustentável nos financiamentos e logram condicionar o desembolso de verbas para infra-estrutura ao desembolso pari passu de verbas para a criação e proteção de áreas de preservação ambiental e terras indígenas. Reflexos desse redirecionamento se fizeram sentir nos procedimentos administrativos de autorização pelo Ibama e pela Funai para a implantação de projetos privados ou governamentais: impõem-se estudos de impacto ambiental (EIA-Rima) como condições prévias a todo projeto de desenvolvimento em áreas de cobertura vegetal nativa ainda intacta ou nas proximidades de terras indígenas.

Porém, esses avanços são desigualmente distribuídos no território nacional, variando não só de um estado a outro, como também segundo as microrregiões 
do mesmo estado e até de município para município. Além disso, os grandes projetos, sobretudo os de âmbito federal, ainda preservam a herança autoritária do período militar. Por exemplo, o Grande Projeto Carajás, oficialmente inaugurado em 1980, não deixou de produzir efeitos semelhantes aos seus homólogos da década anterior, tais como a transmissão de doenças a grupos indígenas recentemente contatados, o deslocamento desses mesmos grupos para áreas que eles desconheciam, o desalojamento de posseiros e os conflitos pela posse da terra com o capital privado que sempre acompanha os empreendimentos desenvolvimentistas do governo. Em termos ambientais, além da poluição dos cursos d'água pela mineração, o Projeto Ferro Carajás atraiu milhares de produtores de carvão vegetal que se estabeleceram ao longo da Ferrovia Carajás para alimentar as usinas de ferro-gusa (cf. Benatti, 1997, p. 88).

Como reflexo da Eco-92, intensifica-se a exigência de setores específicos de proteção ao meio ambiente nas grandes empresas estatais ou de capital misto, como a Petrobras e a Vale do Rio Doce. Porém, tais iniciativas não chegam a se efetivar no terreno. Tais indecisões refletem as contradições inerentes às políticas públicas em esferas mais altas: não deixa de ser um contra-senso que programas voltados para a preservação do ambiente natural, como o Pronabio, partam do mesmo Governo que incentiva o plantio de soja na Amazônia legal através de uma série de programas regionais como o Proceder III, baseados novamente em grande volume de incentivos fiscais para produção, comercialização e escoamento (Carvalho, 1999). Nesse contexto, as hidrovias planejadas, tais como a AraguaiaTocantins e a Tapajós, podem ser interpretadas como estratégias de apoio ao escoamento da produção de soja que irão favorecer também o escoamento da madeira legal ou ilegalmente retirada de áreas de preservação e terras indígenas.

Em termos de preocupações ecológicas, pode-se dizer que houve um avanço em relação aos primeiros grandes projetos, porém, a falta de consenso entre a política de desenvolvimento econômico e a política de preservação ambiental têm como resultado o caráter focal, restrito à maximização dos objetivos econômicos imediatos dos projetos. Trata-se, portanto, de uma cultura ecológica instrumental e limitada, sem referência à globalidade dos sistemas ambientais afetados. Os conhecimentos científicos aplicados nesses projetos limitam-se ao desenvolvimento de técnicas de aproveitamento que garantam a lucratividade máxima do empreendimento econômico, sem incluir nos seus estudos orçamentários uma análise criteriosa dos custos ecológicos envolvidos.

\section{Exploradores itinerantes}

Nesta categoria incluímos os empreendimentos extrativistas que não realizam suas atividades em território próprio, mas em terras devolutas, em propriedades ou posses alheias, ou ainda em unidades territoriais pertencentes à União, como as terras indígenas e as unidades de conservação. Garimpeiros, pescadores profissionais e madeireiros são os três subgrupos principais desta última categoria. Além da mobilidade, outra característica em comum é a exploração meca- 
nizada dos recursos naturais: bombas, dragas, escafandros e aviões no caso dos garimpeiros; barcos motorizados, frigoríficos embarcados, redes de arrasto e malhadeiras de fio sintético no caso dos pescadores; motosserras, tratores e bulldozers no caso dos madeireiros. Nesse sentido, não se trata de exploradores artesanais do meio ambiente, mas de empreendimentos capitalistas com investimentos em equipamentos e meios de transporte que elevam o volume da produção extrativa e também o impacto ambiental da exploração. Contudo, diferenciam-se da exploração empresarial em grande escala não só pela ausência de titulação ou concessão territorial, mas também pela capilaridade e efemeridade da exploração que praticam: penetram os lugares mais recônditos da floresta e permanecem apenas o tempo de esgotar os recursos procurados ou serem expulsos (em geral, pelo Ibama ou pela Funai em conjunto com a Polícia Federal, quando se trata de unidades de conservação ou terras indígenas).

Em termos socioambientais, as decorrências das atividades desses três tipos de exploradores itinerantes são basicamente as seguintes: 1) tendem a esgotar rapidamente os recursos que exploram, pois, não estando restritos a nenhum território específico por tradição ou título de propriedade, não se sentem premidos a poupar ou manejar o ambiente natural; 2) sua presença nas terras que exploram no mais das vezes de forma ilegal depende ou do exercício da violência contra os ocupantes originais ou de alguma forma de aliança econômica com os mesmos; 3 ) essas alianças muitas vezes se traduzem em contratos informais de trabalho com os ocupantes originais, que, sendo em geral bastante pobres, aceitam a exploração de seu patrimônio ambiental e de sua própria mão-de-obra em troca de valores aviltados.

As atividades desenvolvidas por esses exploradores itinerantes apresentam diversas formas de organização, mas todas se distinguem da forma sedentária de extrativismo, contra quem travam os conflitos mais sérios. No caso da pesca, por exemplo, o impacto da pesca comercial sobre os estoques pesqueiros vem ocasionando sérios conflitos entre os moradores ribeirinhos que praticam a pesca artesanal e os pescadores profissionais das frotas comerciais ${ }^{5}$. A sobrepesca nas áreas vizinhas a centros urbanos tem levado os pescadores profissionais a exploraram regiões cada vez mais distantes. É possível encontrar barcos de Manaus e Manacapuru pescando no médio rio Japurá ou acima de Fonte Boa no Solimões. A extensão do conflito em torno da pesca provocou a organização de movimentos sociais importantes, como a implantação de reservas de lagos e sistemas de manejo comunitário da pesca em vários municípios do Amazonas, Pará e Amapá, defendidos pela população local contra a invasão por peixeiros de fora; a formação de redes não governamentais apoiadas por organizações como a Comissão Pastoral da Terra e o Movimento Educacional de Base; e vários projetos de conservação e desenvolvimento sustentável como os Projetos Mamirauá, próximo a Tefé (cf. Ayres et al., 1999), Iara e Várzea (Ruffino, 1999; McGrath et al., 1999), próximos a Santarém. 


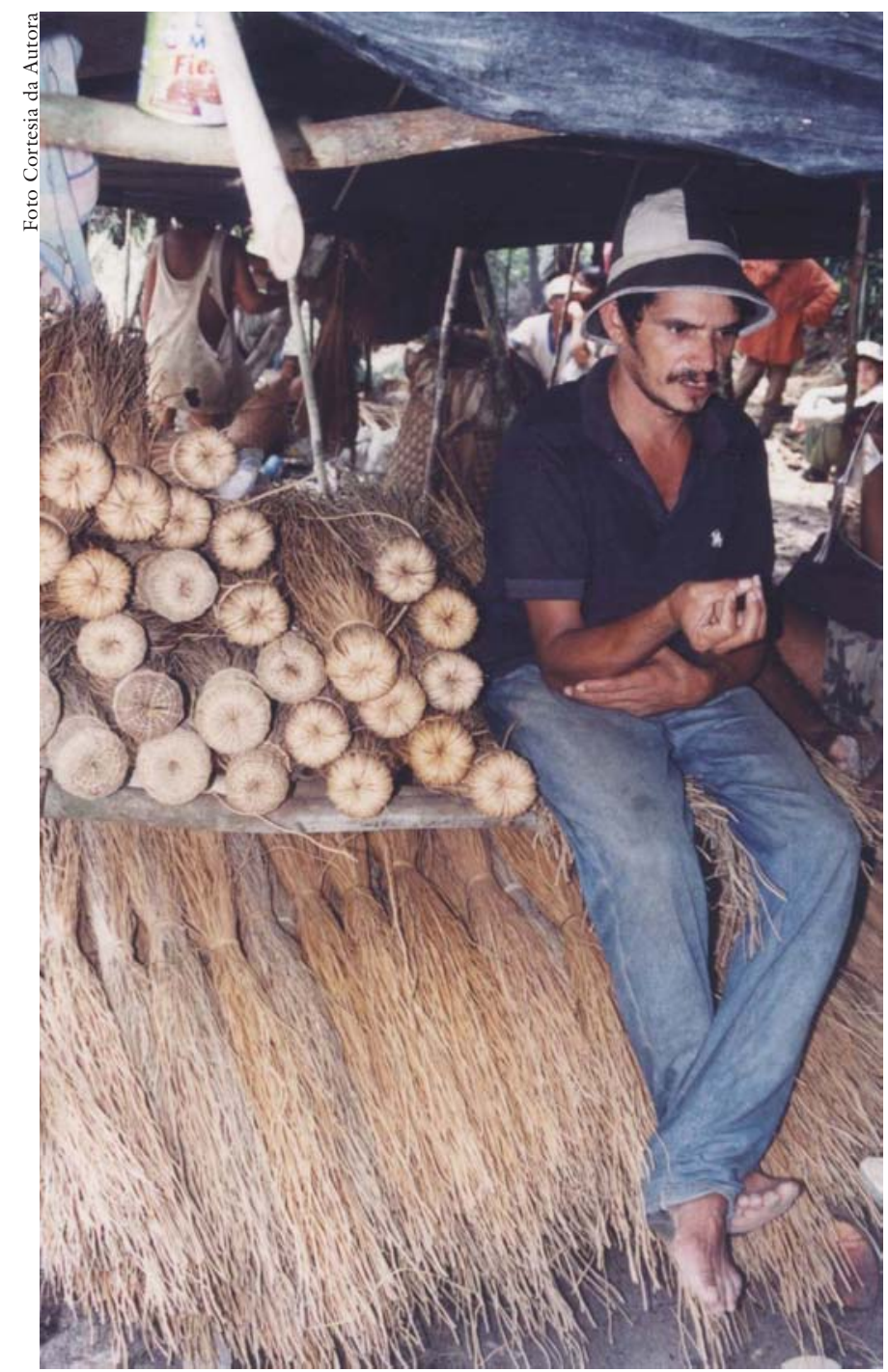

"Patrão" dos indíos katukina

Da mesma forma que a pesca, a extração da madeira e o garimpo são atividades diversificadas quanto à forma das empresas, áreas de exploração e impactos socioambientais. No garimpo do ouro, há diferentes tipos de organização social da atividade extrativa, relacionados aos tipos e à propriedade dos equipamentos utilizados, origens e ocupações paralelas dos trabalhadores, e formas de intermediação e comércio do minério (cf. Petrere, 1991; Schmink e Wood, 1992; Leonel, 1998). Com relação à madeira, a despeito de uma variabilidade de formas de exploração semelhante à do garimpo, há uma distinção básica entre a exploração realizada na várzea e aquela realizada na terra firme (cf. Albernaz e Ayres,1999; Anderson et al., 1999; Barros e Uhl, 1999; Veríssimo et al., 1996).

O apoio ao manejo comunitário dos recursos extrativistas vem sendo apontado como a melhor alternativa para contrapor os impactos negativos da exploração itinerante. Em termos gerais, o interesse da população local em conservar as fontes de sua sobrevivência torna os custos de fiscalização mais baixos. Por 
outro lado, para funcionarem bem, estes sistemas precisam ter uma sólida organização local cujo desenvolvimento pode ser demorado. Apesar dessa dificuldade, o manejo comunitário dos recursos extrativistas é considerado promissor. Além dos projetos ligados à pesca, há também várias experiências de manejo comunitário da madeira, desenvolvidas em áreas indígenas (como entre os Kayapó, cf. Giannini, 1993) e ribeirinhas (como no médio Solimões, na RDS Mamirauá, e no baixo Amazonas, na Ilha Grande de Gurupá). Quanto à exploração do ouro, a experiência dos Wayãpi é um exemplo de como alternativas viáveis podem ser desenvolvidas pelas populações locais (cf. Gallois, 1993).

Ao contrário dos produtores tradicionais, os agentes da exploração itinerante não têm incentivo econômico para desenvolver espontaneamente sistemas de manejo sustentável ou mesmo reduzir o impacto de suas atividades extrativistas. Orientados por uma racionalidade econômica expansionista, exploram os recursos à exaustão, limitados apenas pelo cálculo do lucro imediato, pois não são afetados pela situação futura do recurso explorado. Com esta liberdade, as conseqüências ecológicas de sua exploração são transferidas a outros segmentos sociais, como as populações tradicionais, que têm de arcar com a resolução dos problemas ambientais que provocam.

\section{Conclusão: implicações de uma análise socioambiental}

Neste artigo apresentamos uma classificação de categorias sociais amazônicas baseada no grau de sustentabilidade ecológica de suas formas de uso e ocupação do ambiente. Mostramos que o caráter variável da sustentabilidade ecológica dessas diversas categorias socioambientais associa-se a uma multiplicidade de fatores causais. Sem desprezar o conjunto desses fatores, elegemos a "cultura ecológica" e a "orientação econômica" como principais critérios classificatórios. Tal decisão metodológica conduziu a uma análise empírica da diversidade socioambiental amazônica. O resultado deste exercício foi mostrar que a análise empírica da sustentabilidade ecológica desfaz alguns estereótipos consagrados, tais como o da vocação ecológica dos povos indígenas e o caráter necessariamente depredatório da ocupação não-índia. Contrariando essas representações, concluímos ser preciso analisar as condições específicas que levam determinados segmentos sociais a apresentar um dado padrão de sustentabilidade ecológica.

Apesar de a classificação atribuir menos impacto ecológico a categorias sociais mais distantes da economia de mercado, não queremos dizer que a sustentabilidade ecológica é sempre incompatível com o mercado. A mobilização de populações tradicionais em torno de propostas ecológicas, a existência de um mercado para produtos "verdes" ou de "quarta geração" e a crescente preocupação em conciliar desenvolvimento e conservação são sinais contrários a tal implicação. $\mathrm{O}$ mercado pode não promover sustentabilidade ambiental espontaneamente, mas há novos nichos de mercado a ocupar. No momento atual, entretanto, a extensão de tais propostas de exploração sustentável é precária, como nossa própria análise demonstra. 
Nesse sentido, o conhecimento acerca da diversidade de situações de sustentabilidade e da complexa interação de causas determinantes do tipo de pressão ambiental é indispensável para formular políticas específicas. A análise da diversidade de situações leva à conclusão de que são necessárias ações diferenciadas para promover uma ocupação de baixo impacto.

Tabela 2 - Demandas socioambientais para promover o aumento do grau de sustentabilidade ecológica das categorias analisadas.

\begin{tabular}{|c|c|c|}
\hline Categorias Socioambientais & $\begin{array}{l}\text { Demandas } \\
\text { Ecológicas }\end{array}$ & $\begin{array}{l}\text { Demandas } \\
\text { Sociais }\end{array}$ \\
\hline $\begin{array}{l}\text { Povos indígenas } \\
\text { de comércio esporádico }\end{array}$ & prevenção & assistência e território \\
\hline $\begin{array}{l}\text { Povos indígenas } \\
\text { de comércio recorrente }\end{array}$ & prevenção e manejo & $\begin{array}{l}\text { assistência, território } \\
\text { e acesso ao mercado }\end{array}$ \\
\hline $\begin{array}{l}\text { Povos indígenas } \\
\text { dependentes } \\
\text { da produção mercantil }\end{array}$ & prevenção e manejo & $\begin{array}{l}\text { assistência, território } \\
\text { e alternativas econômicas }\end{array}$ \\
\hline $\begin{array}{l}\text { Pequenos produtores } \\
\text { "tradicionais" }\end{array}$ & prevenção e manejo & $\begin{array}{l}\text { assistência } \\
\text { e território }\end{array}$ \\
\hline Latifúndios "tradicionais" & manejo & incentivos \\
\hline Latifúndios recentes & legislação reguladora & incentivos \\
\hline Migrantes/ fronteira & formação e manejo & $\begin{array}{l}\text { assistência, território e } \\
\text { alternativas econômicas }\end{array}$ \\
\hline Grandes projetos & legislação reguladora & credibilidade \\
\hline Exploradores itinerantes & legislação reguladora & legitimidade social \\
\hline
\end{tabular}

Na Tabela 2 apresentamos algumas demandas ecológicas e sociais que, detalhadas e implementadas por meio de políticas públicas de orientação socio-ambiental, poderão aumentar o grau de sustentabilidade ecológica de cada categoria. Neste contexto analítico, pode-se também justificar a proposta recentemente apresentada pelo movimento ambientalista de que seria justo a sociedade como um todo arcar com alguma forma de pagamento às populações tradicionais por seus "serviços ecológicos". Esta seria não só uma maneira de compensá-las pelos sacrifícios sociais que eventualmente tenham feito para manter seu padrão de baixo impacto ambiental, mas também um incentivo à disseminação de tais comportamentos. 
Para definir indicadores associados a essas categorias socioambientais, incluindo o movimento de recursos e renda gerada por cada segmento, bem como o volume de exploração, o território ocupado e o tamanho da população, seria necessário um estudo mais aprofundado. Assim, as limitações empíricas e teóricas desta análise sugerem caminhos para reflexões mais avançadas sobre a interação complexa dos fatores que explicam o quadro socioambiental da Amazônia em termos da sustentabilidade ecológica.

\section{Notas}

l Este artigo é uma versão reduzida do trabalho publicado em M. A. D'Incao, I. C. Vieira; J. M. C. da Silva e D. Oren (eds.), Diversidade biológica e cultural da Amazônia hoje, Belém, Museu Paraense Emílio Goeldi/ MCT, 2001.

2 Para uma listagem mais ampla de categorias sociais amazônicas, veja Benchimol, 1999.

3 Como define o documento "Carrying for the Earth" (IUCN, Unep e WWF, 1991, p. 198), uma sociedade é ecologicamente sustentável quando "conserves ecological lifesupport systems and biodiversity; ensures that uses of renewable resources are sustainable and minimizes the depletion of nonrenewable resources; keeps within the carrying capacity of supporting ecosystems".

4 Só recentemente, em meados da década de 1980, é que a floresta passou a ter valor econômico, a partir do desenvolvimento da indústria madeireira no sul do Pará (Veríssimo et al., 1996).

5 Para uma classificação dos tipos principais de pescarias na Amazônia, ver Petrere, 1991.

\section{Referências}

ABRAMOVAY, Ricardo. Paradigmas do capitalismo agrário em questão. São Paulo/ Campinas, Hucitec/ Unicamp, 1998.

ALBERNAZ, Ana Luisa e AYRES, José M. "Selective Logging along the Middle Solimões River”. Em C. PADOCH, J. M.; AYRES, M.; PINEDO-VASQUEZ e A. HENDERSON (eds.). Várzea - Diversity, Development, and Conservation of Amazonia's Whitewater Floodplains. New York, NYBG Press, 1999.

ALBERT, Bruce. "Temps du sang, temp des cendres. Représentation de la maladie, système rituel et espace politique chez les Yanomami du sud-ouest (Amazonie Brésilienne)". Tese de Doutorado, Paris, Paris X, 1985.

ALMEIDA, Oriana e UHL, Christopher. "Planejamento do uso do solo do município de Paragominas utilizando dados econômicos e ecológicos". Em ALMEIDA, O. (org.). A evolução da fronteira amazônica - oportunidades para um desenvolvimento sustentável. Belém, Imazon, 1996.

ANDERSON, Anthony; MOUSASTICOSHVILY, Igor e MACEDO, Domingos. "Logging of Virola Surinamensis in the Amazon Floodplain: Impacts and Alternatives". Em PADOCH, C.; AYRES, J. M.; PINEDO-VASQUEZ, M. e HENDERSON, A. (eds.). Várzea-Diversity, Development, and Conservation of Amazonia's Whitewater Floodplains. New York, NYBG Press, 1999. 
ÅRHEM, Kaj. “The Cosmic Food Web”. Em DESCOLA, P. e PÁLSSON, G., Nature and Society, Anthropological Perspectives. London/ New York, Routledge, 1996, pp. 183-204.

ARRUDA, Rinaldo Sérgio Vieira. Relatório antropológico sobre o grupo indígena Salumã (Enawnê-Nawê). São Paulo, Fipe, 1984.

AYRES, José M. et al. "The Conservation of Biodiversity in an Amazonian Flooded Forest". Em PADOCH, C.; AYRES, J. M.; PINEDO-VASQUEZ, M. e HENDERSON, A. (eds.). Várzea - Diversity, Development, and Conservation of Amazonia's Whitewater Floodplains. New York, NYBG Press, 1999.

BALÉE, William. Footprints of the Forest. New York, Columbia University Press, 1994.

BARROS, Ana Cristina e UHL, Christopher. "The Economic and Social Significance of Logging Operations on the Floodplains of the Amazon Estuary and Prospects for Ecolgical Sustainability". Em PADOCH, C.; AYRES, J. M.; PINEDO-VASQUEZ, M. e HENDERSON, A. (eds.). Várzea-Diversity, Development, and Conservation of Amazonia's Whitewater Floodplains. New York, NYBG Press, 1999.

BENATTI, José Eder. “Carajás: desenvolvimento ou destruição?” Em COELHO, M. C. N. e COTA, R. G. (eds.). Dez anos da Estrada de Ferro Carajás. Belém, UFPA/ Naea, 1997.

BENCHIMOL, Samuel. Amazônia-formação social e cultural. Manaus, Valer/ Editora da Universidade do Amazonas, 1999.

BRANFORD, Sue e GLOCK, Oriel. The Last Frontier: Fighitng over Land in the Amazon. London, Zed Books, 1985.

CAPOBIANCO, João Paulo e GIANNINI, Isabelle. Programa de uso sustentável de recursos naturais e recuperação de áreas degradadas da Terra Indígena Xikrin do Cateté. São Paulo, Instituto Socioambiental, 1995, manuscrito.

CARNEIRO DA CUNHA, Manuela e ALMEIDA, Mauro. Populações tradicionais e conservação. Documento de trabalho apresentado no Seminário de Consulta "Avaliação e Identificação de Ações Prioritárias para a Conservação, Uso Sustentável e Repartição dos Benefícios da Biodiversidade da Amazônia Brasileira”. Macapá, Pronabio/ Ministério do Meio Ambiente, 1999.

CARVAlHO, Renata. "Amazônia rumo ao 'ciclo da soja”". Amazônia Papers \# 2, Ano I. Amigos da Terra, Programa Amazônia, 1999.

CHAGNON, Napoléon. Studying the Yanomami. New York, Holt, Rinehart, and Winston, 1974.

CHAYANOV, Alexander V. The Theory of Peasant Economy. Manchester, Manchester University Press, 1966.

CIMA - Comissão Interministerial para a preparação da Conferência das Nações Unidas sobre o Meio Ambiente e Desenvolvimento. O desafio do desenvolvimento sustentável. Brasília, Presidência da República, 1991.

DA MATTA, Roberto. "Panema, uma tentativa de análise estrutural”. Em Ensaios de Antropologia Estrutural. Petrópolis, Vozes, 1973, pp. 63-92.

DESCOLA, Phillipe. In the Society of Nature. A Native Ecology in Amazonia. Cambridge, Cambridge University Press, 1994. 
FORSYTH, Tim; LEACH, Melissa e SCOONES, Ian. Poverty and Environment: Priorities for Research and Policy. Estudo preparado para o PNUD e a Comissão Européia, 1998.

GALLOIS, Dominique T. "Jane Karakuri - O ouro dos Waiãpi: a experiência de um garimpo indígena". Em MAGALHÃES, A. C. (ed.) Sociedades indígenas e transformações ambientais. Belém, Numa/ UFPA, 1993.

GALVÃO, Eduardo. "Panema: uma crença do caboclo amazônico". Revista do Museu Paulista n. V, 1951, pp. 221-225.

. Santos e visagens - um estudo da vida religiosa de Itá, Amazonas. Brasiliana, volume 284. São Paulo, Companhia Editora Nacional, 1955.

GIANNINI, Isabelle V. "Sociedade e meio ambiente: um estudo de caso". In MAGALHÃES, A. C. (ed.). Sociedades indígenas e transformações ambientais. Belém, Numa/ UFPA, 1993.

GROSS, Daniel. "Protein Capture and Cultural Development in the Amazon Basin”. American Anthropologist 77, 1975, pp. 526-549.

HALL, Anthony. Amazônia, desenvolvimento para quem? Desmatamento e conflito social no programa Grande Carajás. Rio de Janeiro, Zahar, 1991.

HARRIS, Mark. "People of the Amazon Floodplain: Kinship, Work and Sharing in a Caboclo Community near Óbidos, Pará”. Tese de Doutorado, London, London School of Economics and Political Science, Universidade de Londres, 1996.

HÉBETTE, Jean. “A ocupação camponesa de uma área de fronteira e sua dinâmica social: o caso de Pau-Seco/ Cametau". Atas do Seminário Agricultura Familiar e Desenvolvimento Rural na Amazônia Oriental. Agricultures Paysannes et Developpement: Caraïbe - Amérique Tropicale, Hors Série. Pointe-à-Pitre, Universidade das Antilhas e da Guaian, 1991.

HUGH-JONES, Stephen. "Yesterday's Luxuries, Tomorrow's Necessities: Business and Barter in Northwest Amazonia”. Em HUMPHREY, C. e HUGH-JONES, S. (orgs.). Barter, Exchange and Value. An Anthropological Perspective. Cambridge, Cambridge University Press, 1992.

IANNI, Octávio. Colonização e contra-reforma agrária. Petrópolis, Vozes, 1979a.

- A luta pela terra. História social da terra e da luta pela terra numa área da Amazônia. Petrópolis, Vozes, 1979b.

IUCN, WWF, Unep. Caring for the Earth: A Strategy for Sustainable Living. Gland, 1991.

LEONEL, Mauro. A morte social dos rios - conflito, natureza e cultura na Amazônia. São Paulo, Perspectiva/ Iamá/ Fapesp, 1998.

LIMA AYRES, Deborah de Magalhães. “The Social Category 'Caboclo’: History, Social Organization, Identity and Outsiders Identification of the Rural Population of an Amazonian Region”. Tese de Doutorado, Cambridge, Universidade de Cambridge, 1992.

. "Eqüidade, desenvolvimento sustentável e conservação da biodiversidade". Em Faces do trópico úmido - conceitos e questões sobre desenvolvimento e meio ambiente. CASTRO, Edna e PINTON, Florence (eds.). Belém, Cejup, 1997. 
. "Relatório da apresentação do Projeto Corredores Ecológicos aos Povos Indígenas do Médio e Alto Solimões”. Brasília, Ibama/ PPG-7, 1998, manuscrito.

LIZOT, Jacques. "Populations, ressources et guerre chez les Yanomami". Libre, 2, 1977, pp. 111-115.

MACEDO, Domingos S.; GIANNINI, Isabelle e TATTO, Nilto. "Programa de uso sustentável de recursos naturais e recuperação de áreas degradadas da Terra Indígena Xikrin do Cateté. Segundo relatório de atividades." São Paulo, Instituto Socioambiental, 1977, manuscrito.

MACEDO, Domingos S.; GIANNINI, Isabelle; ANDREAS, Fabíola e LADEIRA, Francisco B. "Programa de uso sustentável de recursos naturais e recuperação de áreas degradadas da terra indígena Xikrin do Cateté. Terceiro relatório de atividades”. São Paulo, Instituto Socioambiental, 1977, manuscrito.

MATTOS, Marli e UHL, Christopher. "Perspectivas econômicas e ecológicas da pecuária na Amazônia oriental na década de 90: o caso Paragominas”. Em ALMEIDA, O. (org.). A evolução da fronteira amazônica-oportunidades para um desenvolvimento sustentável. Belém, Imazon, 1996.

McGRATH, David; CASTRO, Fábio de; CÂMARA, Evandro e FUTEMMA, Célia. "Community Management of Floodplain Lakes and the Sustainable Development of Amazonian Fisheries”. Em PADOCH, C.; AYRES, J. M.; PINEDO-VASQUEZ, M. e HENDERSON, A. (eds.). Várzea - Diversity, Development, and Conservation of Amazonia's Whitewater Floodplains. New York, NYBG Press, 1999.

MEGGERS, Betty. Amazônia: a ilusão de um paraíso. Rio de Janeiro, Civilização Brasileira, 1977.

MEIRA, Márcio. No tempo dos patrões: extrativismo da piaçava entre os indios do rio Xié (alto rio Negro). Dissertação de Mestrado, Campinas, Unicamp, 1993.

MORAN, Emílio F. “The Trans-Amazonica: Coping with a New Environment”. Em MARGOLIS, Maine e CARTER, William E. (eds.). Brazil, Anthropological Perspectives: Essays in Honor of Charles Wagley. New York, Columbia University Press, 1979.

NUGENT, Stephen. Amazonian Caboclo Society. Providence/ Oxford, Berg, 1993.

OLIVEIRA FILHO, João Pacheco. “O nosso governo" - os Ticuna e o regime tutelar. São Paulo/ Marco Zero e MCT-CNPq, 1988.

(coord.). “Atlas das Terras Ticunas”. Rio de Janeiro, Projeto Museu Nacional/ Finep/ PPG-7/ Cgtt, 1998, manuscrito.

OLIVEIRA, Ana Gita de; MEIRA, Márcio; POZZOBON, Jorge. Relatório antropológico, áreas indigenas médio rio Negro, rio Téa e rio Apapóris. Brasília, Funai, 1994.

PETRETE, Miguel. "As comunidades humanas ribeirinhas da Amazônia e suas transformações sociais”. Em DIEGUES, A. C. (org.). Populações humanas, rios e mares da Amazônia - Anais do IV Encontro de Ciências Sociais e Mar no Brasil. São Paulo, PPCAUB - USP, 1991.

POZZOBON, Jorge. “O lumpen indigenismo do Estado brasileiro”. Journal de la Société des Américanistes. 85, 1999, pp. 282-306.

RIBEIRO, Darcy. Os indios e a civilização. Rio de Janeiro, Civilização. Brasileira, 1970. RICARDO, Fany. “Terras indígenas na Amazônia legal”. Documento de trabalho apre- 
sentado no Seminário de Consulta “Avaliação e Identificação de Ações Prioritárias para a Conservação, Uso Sustentável e Repartição dos Benefícios da Biodiversidade da Amazônia Brasileira”. Macapá, Pronabio/ Ministério do Meio Ambiente, 1999.

ROSS, Eric. "Food Taboos, Diet, and Hunting Strategies: the Adaptation to Animals in Amazon Cultural Ecology". Current Anthropology 19, 1978, pp. 1-19.

RUFFINO, Mauro. "Fisheries Development in the Lower Amazon River". Em PADOCH, C.; AYRES, J. M.; PINEDO-VASQUEZ, M. e HENDERSON, A. (eds.). Várzea - Diversity, Development, and Conservation of Amazonia's Whitewater Floodplains. New York, NYBG Press, 1999.

SLATER, Candace. Dance of the Dolphin - transformation and disenchantment in the amazonian imagination. Chicago e Londres, The University of Chicago Press, 1994.

SCHMINK, Marianne e WOOD, Charles. Contested Frontiers in Amazonia. New York, Columbia University Press, 1992.

UHL, Christopher e ALMEIDA, Oriana. "O desafio da exploração sustentada da Amazônia”. Em ALMEIDA, O. (org.). A evolução da fronteira amazônica-oportunidades para um desenvolvimento sustentável. Belém, Imazon, 1996.

VERÍSSIMO, Adalberto; BARRETO, Paulo; MATTOS, Marli; TARIFA, Ricardo e UHL, Christopher. "Impactos da atividade madeireira e perspectivas para o manejo sustentável da floresta numa velha fronteira da Amazônia: o caso Paragominas". Em ALMEIDA, O. (org.). A evolução da fronteira amazônica-oportunidades para um desenvolvimento sustentável. Belém, Imazon, 1996.

VERÍSSIMO, José. Estudos amazônicos. Coleção Amazônica, Série José Veríssimo. Belém, Universidade Federal do Pará, 1970 [1878].

VILLELA, Annibal. Desenvolvimento econômico da Amazônia. Belém, Universidade Federal do Pará, 1966 (Col. Amazônica, Série Augusto Montenegro).

WAGLEY, Charles. Amazon Town, A Study of Man in the Tropics. London/ Oxford/ New York, Oxford University Press, 1976[1953].

RESUMO - ESTE ARTIGO baseia-se no emprego de um conceito central do discurso ambientalista - o de sustentabilidade ecológica - para construir um quadro analítico da diversidade socioambiental da Amazônia contemporânea. O exercício consiste em um ordenamento geral de categorias sociais segundo seu comportamento ambiental. Este é o ponto de partida para uma análise dos fundamentos históricos, econômicos e culturais da sustentabilidade ecológica atribuída a cada segmento social. A análise mostra a complexidade da interação entre múltiplos fatores que explicam o comportamento ecológico particular de cada um dos seguintes segmentos sociais considerados: a) povos indígenas de comércio esporádico, b) povos indígenas de comércio recorrente, c) povos indígenas dependentes da produção mercantil, d) pequenos produtores "tradicionais", e) latifúndios "tradicionais", f) latifúndios recentes, g) migrantes/ fronteira, h) grandes projetos e i) exploradores itinerantes. Com este exercício, alguns estereótipos consagrados são contrariados, como aqueles que relacionam baixa sustentabilidade ecológica com pobreza, ou alta sustentabilidade ecológica com identidade indígena. Concluímos mostrando a importância de prosseguir com análises de amplo espectro para entender a diversidade socioambiental da Amazônia. 
Palavras-chave: Amazônia; sustentabilidade ecológica; diversidade socioambiental; comportamento ecológico.

ABSTRACT - WITH ONE of the central concepts of environmental discourse - that of ecological sustainability - we analyse the social diversity of contemporary Amazonia, presenting classification of Amazonian social segments according to the degree of environmental sustainability of their productive activities. With no intention of covering all of Amazonian social diversity, we identify nine of its main segments: Indians of sporadic commerce, Indians of recurrent commerce, Indians dependent on mercantile production, traditional peasants, traditional ranchers, recently established ranchers, frontier migrants, large scale entrepreneurial projects, and itinerant extraction producers. The analysis of each socio-environmental category takes into account the characteristics of their economic orientation and ecological cultures. Besides these features, the complex interaction among multiple asocial and environmental factors is demonstrated to explain the specific ecological behaviour displayed by each social segment. With this exercise, some consecrated stereotypes are proven false, such as those that indicate negative correlations between sustainability and demographic density or poverty, and positive correlations between sustainability and Indian identity. We conclude by pointing out the importance of following broad-spectrum analyses in order to understand the socio-environmental diversity of contemporary Amazonia.

Key-words: Amazonia; ecological sustainability; socio-environmental diversity; ecological behaviour.

Deborah Lima é professora no Departamento de Sociologia e Antropologia da Faculdade de Filosofia e Ciências Humanas da Universidade Federal de Minas Gerais (UFMG). @ - deb.lima@terra.com.br

Jorge Pozzobon era professor do Departamento de Ciências Sociais do Museu Paraense Emílio Goeldi, MCT/ CNPq. Falecido precocemente em 2001, deixou para a antropologia amazônica uma importante contribuição etnológica e, em seus amigos, muitas saudades.

Versão ampliada deste texto foi publicada originalmente em VIEIRA, Célia Guimarães Ima et al. (orgs.). Diversidade biológica e cultural da Amazônia. Belém, Museu Paraense Emílio Goeldi, 2001, pp. 195-251.

Texto recebido em 30/4/2005 e aceito em 16/5/2005. 